\title{
Wireworms in Florida Sugarcane ${ }^{1}$
}

\author{
R. H. Cherry and M. Karounos ${ }^{2}$
}

Wireworms, the larval stage of a click beetle, often cause severe damage to numerous crops in Florida. At least twelve species of wireworms have been found in southern Florida, but only the corn wireworm, Melanotus communis, is considered to cause significant economic damage to sugarcane. Since M. communis is the important wireworm species, the rest of this document will pertain to this species.

\section{Biology}

Adult click beetles may be collected during all months of the year, but they are most numerous during May, June, and July and are scarce from September to March. The beetles are brown and about $5 / 8$ " long.

The larvae of click beetles are called wireworms because they resemble a jointed piece of stiff, bright, brownishyellow wire. M. communis wireworms are approximately $1-1 / 4$ inch long when fully grown (Figure 1). They are soil pests and attack the underground portions of the sugarcane plant.

Wireworms are generally found under sugarcane stools (or roots; please see Sugarcane Botany: A Brief View, https://edis.ifas.ufl.edu/sc034, for further information on sugarcane anatomy) rather than between stools in a row or between rows. Wireworm populations are lowest in

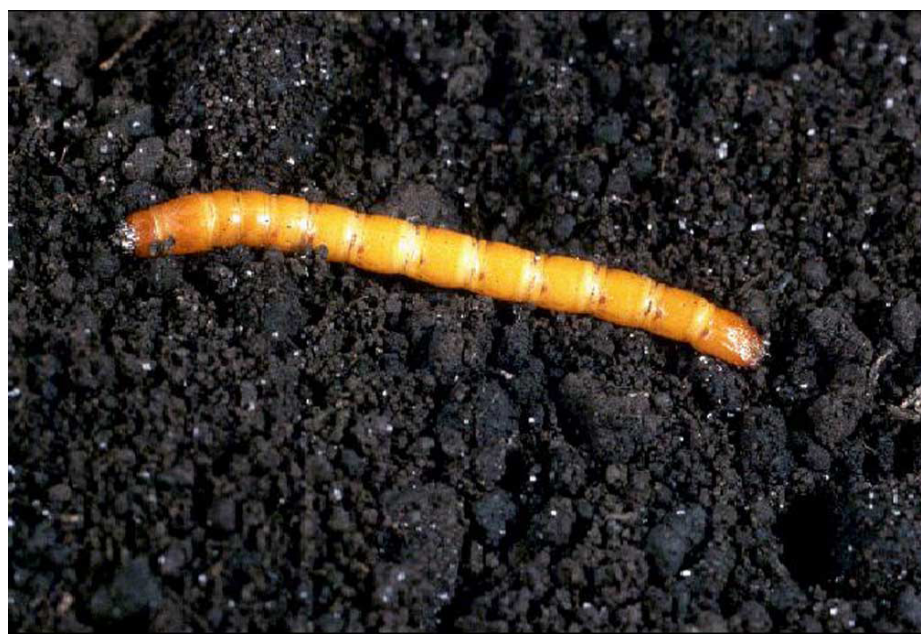

Figure 1. Wireworm larva.

Credits: Ron Cherry, UF/IFAS

the summer and increase rapidly in the fall, staying fairly constant thereafter. However, M. communis are slightly smaller in the fall than during the rest of the year.

Laboratory tests indicate that weeds in and around sugarcane fields are not major attractants for M. communis. Both the adults and larvae preferred to reside in sugarcane juices and root material rather than respective weedy plant materials in free choice tests in the lab. In tests, this effect varied by sugarcane cultivar and soil type.

1. This document is ENY-665, one of a series of the Entomology and Nematology Department, UF/IFAS Extension. Original publication date October 1991. Revised February 2008, April 2011, and March 2014. Reviewed and revised March 2021. Visit the EDIS website at http://edis.ifas.ufl.edu for the currently supported version of this publication. This publication is also a part of the Florida Sugarcane Handbook, an electronic publication of the Agronomy Department. For more information, contact the editor of the Sugarcane Handbook, Hardev Sandhu (hsandhu@ufl.edu).

2. R. H. Cherry, professor; and M. Karounos, biological scientist, Entomology and Nematology Department; UF/IFAS Everglades Research and Education Center, Belle Glade, FL 33430.

The use of trade names in this publication is solely for the purpose of providing specific information. It is not a guarantee or warranty of the products named and does not signify that they are approved to the exclusion of others of suitable composition.

The Institute of Food and Agricultural Sciences (IFAS) is an Equal Opportunity Institution authorized to provide research, educational information and other services

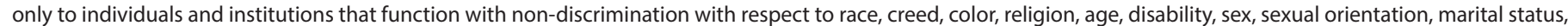

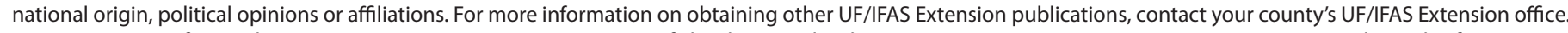
U.S. Department of Agriculture, UF/IFAS Extension Service, University of Florida, IFAS, Florida A \& M University Cooperative Extension Program, and Boards of County Commissioners Cooperating. Nick T. Place, dean for UF/IFAS Extension. 


\section{Damage}

Generally, wireworms are a pest of newly planted sugarcane and only rarely a pest in ratoon sugarcane. Wireworms feed on the buds and root primordia during germination of sugarcane seed pieces and on shoots and roots after germination. Most of the injury to young shoots is near the point where the shoots join the seed piece or stubble. Wireworm injury can generally be identified as relatively large, ragged holes cut into seedpieces and buds or into young shoots. The death of buds or young shoots leads to stand reductions. Wireworm injury has been reported as facilitating the entrance of the fungus that causes sugarcane red rot disease.

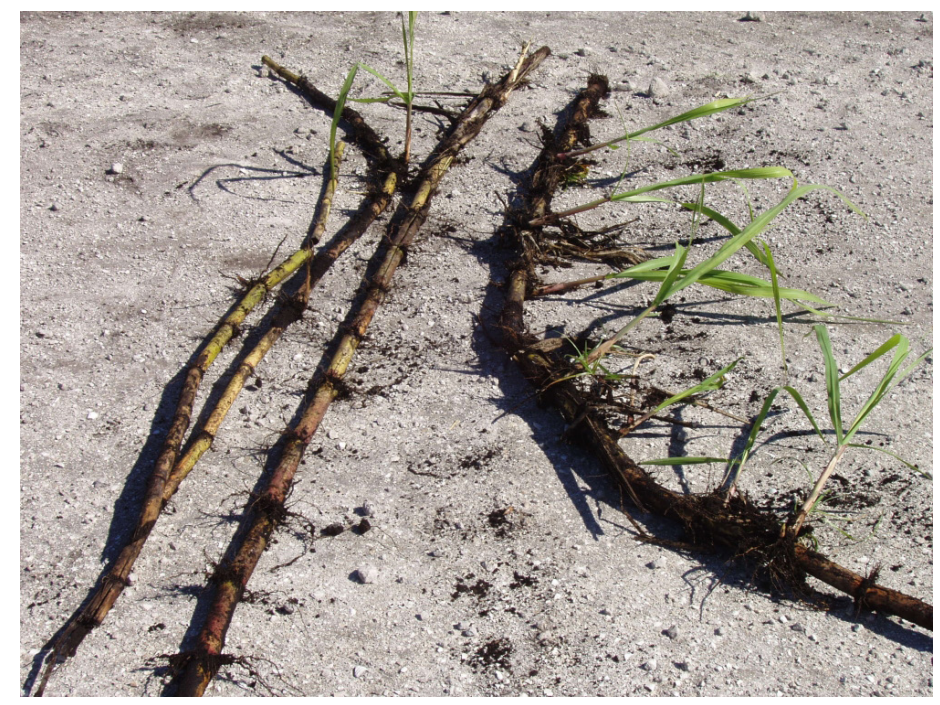

Figure 2. Sugarcane stalks on left show wireworm damage to germinating buds versus the stalk on right protected with a soil insecticide.

Credits: Ron Cherry, UF/IFAS

Field studies have shown that significant stand reductions during early plant growth may occur at infestation levels of fewer than 4 wireworms per 5 feet of row. One recent study showed that one wireworm per 5 row feet could cause $6.2 \%-7.8 \%$ stand reduction at twelve weeks after planting. Tillering may compensate for some of the early stand losses, but at harvest stalks from infested sugarcane fields tend to weigh less.

In a large plot study, the weight of cane harvested was reduced by $3.8 \%$ per wireworm per 5 feet of row. Stand reductions in plant cane caused by 8 to 12 wireworms per 5 feet of row carried over into the first ratoon crop and resulted in lower ratoon crop yield.

\section{Control}

\section{Biological Control Practices}

Although there are a small number of insect parasites that attack wireworms, biological control of wireworms in south Florida by beneficial insects and diseases has generally been considered to be insignificant. Birds such as the cattle egret may sometimes be of value in reducing wireworm levels because they may consume wireworms that are exposed at the surface of the soil when a field is disked or cultivated.

\section{Cultural Control Practices}

Flooding for wireworm control can be effective but is a slow process and may not be practical. More studies are needed, but the current information suggests substantial percentages (e.g., $40 \%$ or more) of wireworms could be killed by flooding but in general the flood duration had to be at least 4 to 5 weeks at water temperatures above $24^{\circ} \mathrm{C}$. A minimum of six weeks of continuous flooding is needed during the summer to obtain complete wireworm control. Longer flooding durations are needed during colder months.

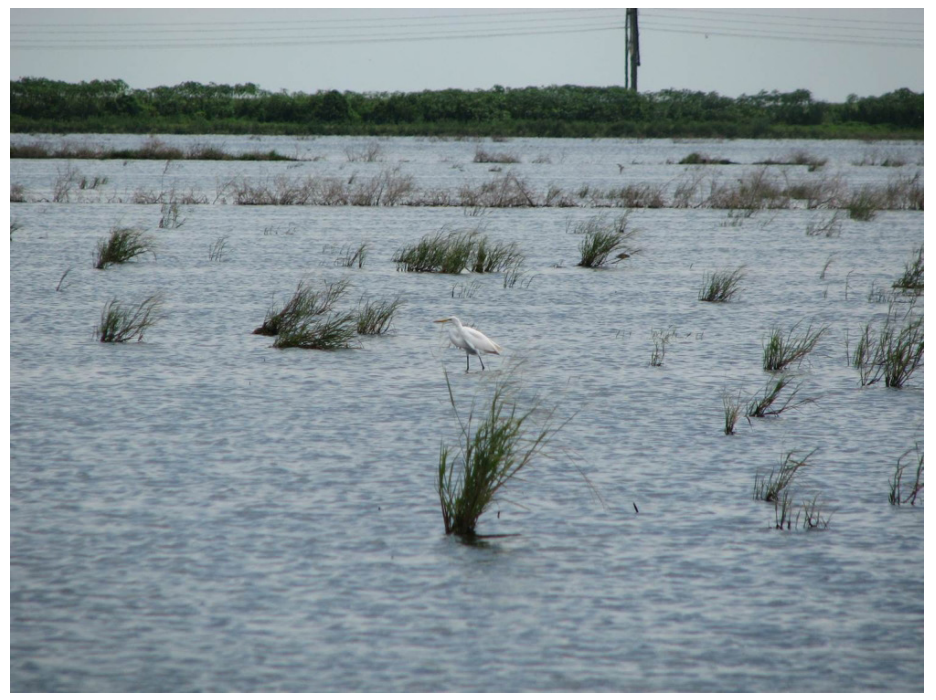

Figure 3. Fallow field flooding is used in Florida to control wireworm populations.

Credits: Ron Cherry, UF/IFAS

Flooding during late spring and summer will kill the wireworms and also prevent egg-laying by the adult click beetles. Flooding fallow fields or growing rice as a rotation crop may eliminate the need to use a soil insecticide at sugarcane planting the following fall. Growing a ratoon rice crop may offer slightly increased control during years when click beetle activity extends into July and August.

Tests were conducted in southern Florida fallow fields to determine the effect of weed control on wireworm populations. These tests showed that fields in which weeds 
were controlled by either herbicide treatment or disking exhibited lower wireworm populations than fields in which weeds were allowed to grow.

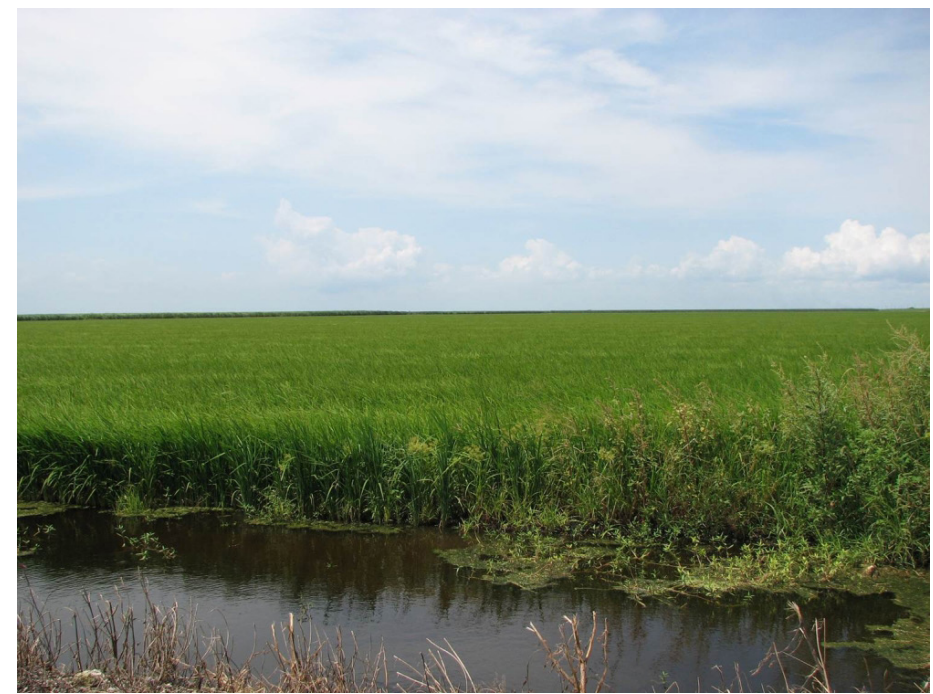

Figure 4. Soil insecticides are generally not needed after rice crops because of the extended flooding.

Credits: Mike Karounos, UF/IFAS

\section{Chemical Control Practices}

Soil insecticides are generally used in newly planted sugarcane for wireworm control. Insecticides are not used for wireworm control in ratoon sugarcane. No resistance to insecticides has been reported to occur in wireworms in Florida sugarcane.

Some Florida sugarcane growers do not use a soil insecticide at planting knowing that previous flooding of fallow fields or rice fields reduces wireworm populations. However, these fields account for only a small percent of sugarcane fields. Florida sugarcane growers on sandy soils sometimes do not use a soil insecticide at planting in the belief that fewer wireworms are in sand than are in muck soils. Again, these fields account for only a small percent of sugarcane fields, and a study did report that high wireworm populations do occur there, although not as frequently as in muck soils. Another study concluded that label rates for phorate, a soil insecticide for wireworm control in Florida sugarcane, may be higher than necessary for effective control. These previous studies have brought into question when to use soil insecticides at sugarcane planting.

\section{Sampling}

Pheromone traps or a simpler sequential sampling method can be used to monitor seasonal wireworm populations and determine when other control measures are necessary.

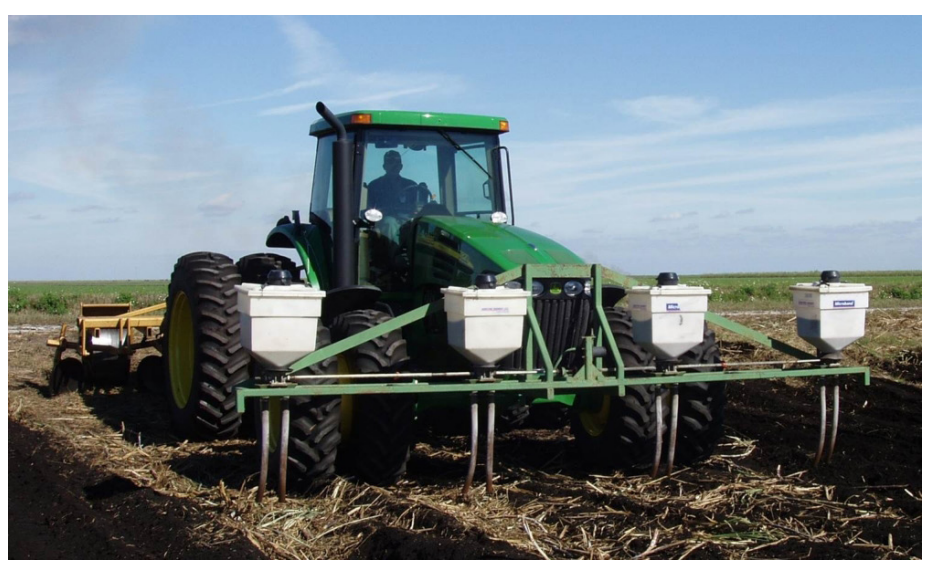

Figure 5. Soil insecticides are frequently used for wireworm control when planting sugarcane.

Credits: Ron Cherry, UF/IFAS

A simple sampling method has been tested that may be of use to Florida sugarcane growers to determine the necessity of soil insecticide application at planting. Wireworm samples taken in a transect across the length of each field using an economic injury level of nine or more wireworms per 25 samples accurately predicted appropriate economic thresholds in field tests.

Pheromone traps for click beetles have an important function in wireworm management for both mass trapping and monitoring in other agricultural systems but are untested in Florida sugarcane. Pheromones are chemical signals used by adult female click beetles. Pheromones are isolated, synthesized in lab, and produced to make traps to attract click beetles. While pheromone traps are routinely employed as research tools to monitor populations of the genus Agriotes in Europe and North America, their only testing with the genus has been in Japan and more recently in South Carolina where a compound specifically attractive to Melanotus communis was tested in corn, sweet potato, and cucumber fields.

\section{Selected References}

Cherry, R., P. Grose, and E. Barbieri. 2013. "Validation of a Sequential Sampling Plan for Wireworms (Coleoptera: Elateridae) at Sugarcane Planting." Journal of Pest Science 86:29-32.

Cherry, R., and P. Stansly. 2008. "Abundance and Spatial Distribution of Wireworms (Coleoptera: Elateridae) in Florida Sugarcane Fields on Muck Versus Sandy Soils." Florida Entomologist 91:383-387. 
Cherry, R., and P. Stansly. 2009. "Impact on Yield of Wireworm (Coleoptera: Elateridae) Populations in Florida Sugarcane at Planting." Journal of American Society of Sugar Cane Technologists 29:137-148.

Coale, F., and O. Sosa. 1991. "Sugarcane Yield Response to Soil Insecticides in the Everglades Agricultural Area." Journal of American Society of Sugar Cane Technologists 11:23-28.

Hall, D. 1990. "Stand and Yield Losses in Sugarcane Caused by the Wireworm Melanotus communis (Coleoptera: Elateridae) Infesting Plant Cane in Florida." Florida Entomologist 73:298-302.

Hall, D., and R. Cherry. 1993. "Effect of Temperature on Flooding to Control the Wireworm Melanotus communis (Coleoptera: Elateridae)." Florida Entomologist 76:155-160.

Karounos, M., R. Cherry, D. Odero, H. Sandhu, and J. Beuzelin. 2019. "Host Plant Preference of Melanotus communis (Coleoptera: Elateridae) among Weeds and Sugar Cane Varieties Found in Florida Sugar Cane Fields." Florida Entomologist 102:403-7.

Larsen, N., and G. Nuessly. 2009. "Effectiveness of Reduced Rates of Insecticides for the Control of Melanotus communis (Coleoptera: Elateridae) in Sugarcane." Florida Entomologist 92:629-634.

Larsen, N., G. Nuessly, R. Cherry, and B. Glaz. 2013. "Varietal Susceptibility to the Corn Wireworm Melanotus communis (Coleoptera: Elateridae) in Sugarcane." Journal of Pest Science 86:91-98

Rainbolt, C., and R Cherry. 2008. "Effect of Weed Control on Wireworm (Coleoptera: Elateridae) Populations in Fallow Fields in Southern Florida." Journal of Entomological Science. 43:138-140.

Van Herk, W., and R. Vernon. 2020. "Local Depletion of Click Beetle Populations by Pheromone Traps Is Weather and Species Dependent." Environmental Entomology. 49:449-460.

Williams, L., J. Serrano, P. Johnson, and J. Millar. 2019. "13-Tetradecenyl Acetate, a Female-Produced Sex Pheromone Component of the Economically Important Click Beetle Melanotus communis (Gyllenhal) (Coleoptera: Elateridae)." Scientific Reports 9 (1): 16197. doi: 10.1038/ s41598-019-52199-1. PMID: 31700046; PMCID:

PMC6838319. 